\title{
高分子材料を中心とした宇宙用材料の 耐宇宙環境性評価
}

森一之，宮崎 英治

\section{Evaluations of Polymeric Materials in Space Environment for Space Use}

Kazuyuki MORI and Eiji MIYAZAKI (Japan Aerospace Exploration Agency, Aerospace Research and Development Directorate, Tsukuba Space Center, 2-1-1 Sengen, Tsukuba, Ibaraki 305-8505, Japan)

Wide-ranging polymeric materials are commonly used in spacecraft to meet numerous system design requirements. The tolerance of such polymeric materials against the space environment, e.g. vacuum, ultraviolet rays, radiation, atomic oxygen, etc. must be evaluated, because this environment is a known threat for materials, especially polymers. JAXA has been striving to evaluate the tolerance of polymeric materials in the space environment through both ground tests and space exposure experiments, which allows engineers in the space industry to obtain material data detailing tolerance against the space environment. This article introduces the space environment and its effect on polymeric materials, examples of damage to materials in orbit, and the evaluation capabilities for polymeric materials to be used in space at the Tsukuba Space Center, JAXA.

Key Words : Space Environment, Ultraviolet, Atomic Oxygen, Degradation

\section{1.はじめに}

人工衛星やロケットに代表される宇宙機には，多くのソ フトマテリアル（高分子材料）が使用されている. 例えば, 宇宙機の最外層に使用される高分子フィルムやフォーム 材, 電線被覆材, 電子回路の基板等がある. 人工衛星の写 真で，表面が金色にかがやているのを見たことが有ると思 うが，それはポリイミドフィルム（黄色透明）の裏面に $\mathrm{Al}$ 蒸着したものである。最近では，太陽光圧を受けて 進む「ソーラーセイル」のような極薄高分子フィルムの応 用例も出てきた ${ }^{1)}$.

宇宙機に高分子材料が用いられるのは，重量や施工性等 種々の制約条件をクリアするためである。一方，宇宙機が 曝される環境は,材料に対して厳しいことが知られている. そして, 高分子材料は金属材料や無機材料と比心耐環境性 に劣ることが多い。このような背景から，宇宙で使用する 材料は宇宙環境に対する評価が必要であり，それは，主と して高分子材料に対して適用されている.

本稿では，まず宇宙特有の環境，材料の劣化モードにつ いて述へ，軌道上での材料劣化の例を紹介する，次に，宇 宙環境を模擬した地上対象試験と研究事例を紹介する。

\section{2. 宇宙環境と材料劣化及び事例}

\section{1 宇宙環境}

宇宙で使用される高分子材料は, 温度サイクル, 紫外線, 高層大気の酸素分子が太陽エネルギーで解離され生成され る原子状酸素, 放射線, 高真空といった過酷な環境に曝さ れる。ここでは, 宇宙環境として代表的な, 温度サイクル, 紫外線，原子状酸素の各環境について紹介する.

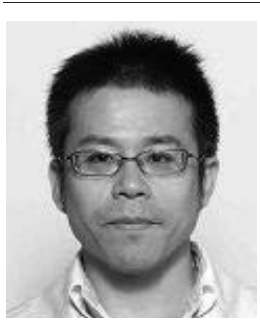

森 一之; 独立行政法人宇宙航空研究開発機 構 研究開発本部. 電子部品・デバイス・材料 グループ（† 305-8505 茨城県つくば市千現 21-1). 平成 13 年名古屋工業大学大学院工学研 究科博士前期課程 (物質工学専攻) 修了. 平 成 13 年宇宙開発事業団（現宇宙航空研究開発 機構）入社. 現在に至る. 専門は材料工学. 材料の耐宇宙環境性の研究, 材料評価試験の 効率化検討等に従事。

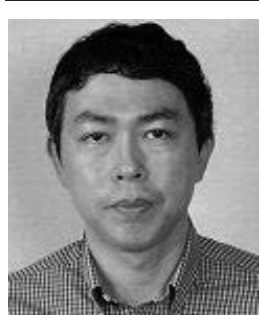

宮崎 英治；博士（工学）。独立行政法人宇宙航空 研究開発機構研究開発本部。電子部品・デバイス。 材料グループ ( テ305-8505 茨城県つくば市千現 2 $1-1)$. 平成 10 年早稲田大学理工学研究科資源及材 料工学専攻修士課程修了。平成 10 年宇宙開発事業 団（現宇宙航空研究開発機構）入社. 平成 12 年東 京工業大学へ出向し, 総合理工学研究科助手を経て, 平成 15 年に復帰, 現在に至る。専門は材料工学, 宇宙材料学. 日本航空宇宙学会平成 25 年度材料部 門委員. 


\subsection{1 温度環境}

宇宙機の外表面は日照時には $+120{ }^{\circ} \mathrm{C}$, 地球の陰に入る 日陰時においてはー $120{ }^{\circ} \mathrm{C}$ になる。高度数百 $\mathrm{km}$ の低高度 地球周回軌道（LEO: Low Earth Orbit）を飛行する人工 衛星や国際宇宙ステーション (ISS: International Space Station）は，地球を約 90 分で 1 周するため， 1 日に約 16 回，設計寿命が 10 年の場合には，約 55,000 回の温度サイ クルを受けることになる。高度 $36,000 \mathrm{~km}$ の静止軌道 (GEO: Geostationary Earth Orbit) を飛行する気象衛星 や通信衛星は，1年間に約 90 回地球の影に入り，その際に 温度が大きく変化する. 10 年間で約 900 回の温度サイクル を受ける.

この大きな温度変化への対策の一つとして, 高分子フィ ルムを積層した多層断熱材（MLI: Multi Layer Insulation） を初めとする様々な熱制御材料を使用した熱制御を行い, 宇宙機各部の温度が搭載機器の許容温度範囲に入るように 設計されている。

\subsection{2 紫外線（UV: Ultraviolet）環境}

AM0（Air Mass 0, 大気圈外) ${ }^{2)}$ における太陽光スペク トル分布を図 1 に示す。太陽光の強度は波長約 $200 \mathrm{~nm}$ か ら高くなり，波長約 450〜 $500 \mathrm{~nm}$ にピークを有する.

$\mathrm{UV}$ 波長域 $(200 \sim 400 \mathrm{~nm})$ 前後の $\mathrm{AM} 0^{2)}$ 及び $\mathrm{AM} 1.5 \mathrm{G}$ (Air Mass 1.5 Global tilt, 地上) ${ }^{3)}$ における太陽光スペク

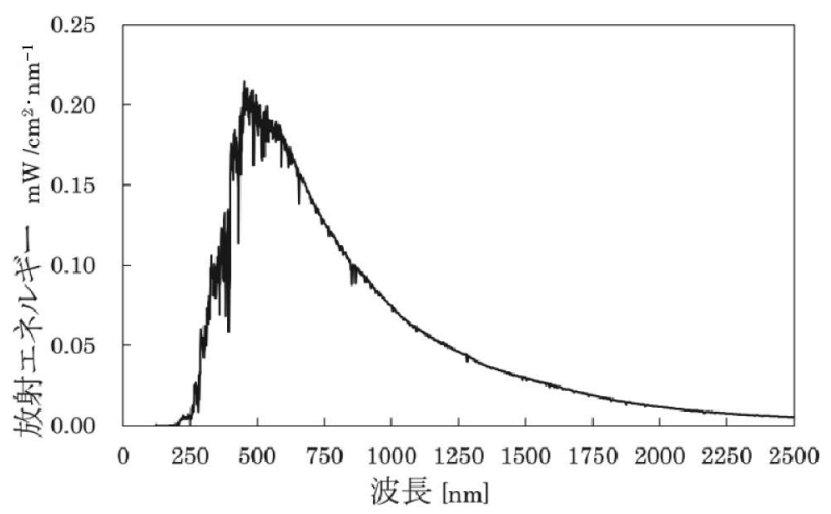

図 $1 \mathrm{AM} 0$ の太陽光スペクトル分布 ${ }^{2)}$

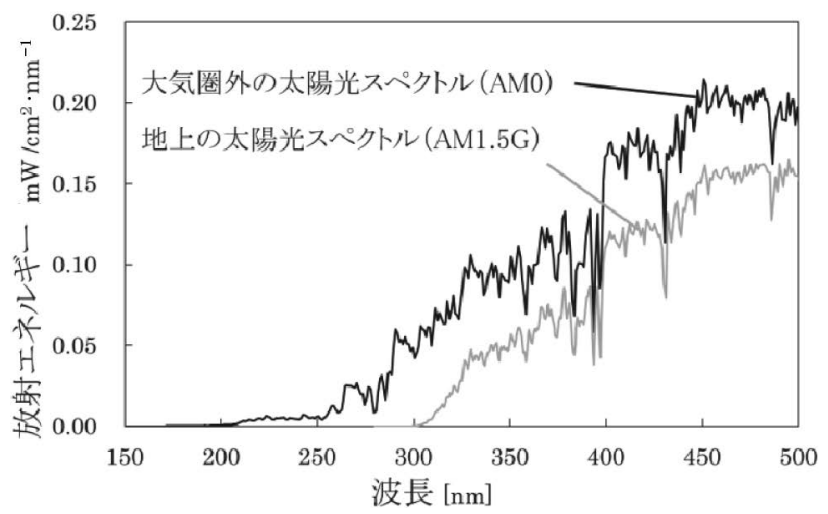

図2 $\mathrm{AM} 0^{2)}$ 及び $\mathrm{AM} 1.5 \mathrm{G}^{3)}$ の太陽光スペクトル分布 (UV 波長域前 後) の比較
トル分布を図 2 に示す。図 2 から，地上では大気により弱 められる $300 \mathrm{~nm}$ 以下のUVも宇宙空間では存在している ことがわかる.

軌道上で宇宙機が曝されるUVフラックスは，AM0に おける太陽光スペクトル強度を積分することで求められ る. 近紫外域 200 ～ $400 \mathrm{~nm}$ の波長域を積分すると 118 $\mathrm{W} / \mathrm{m}^{2}\left(11.8 \mathrm{~mW} / \mathrm{cm}^{2}\right)$ のフラックスとなる.

\subsection{3 原子状酸素（AO: Atomic Oxygen）環境}

高層大気では, 太陽から降り注ぐUVにより酸素分子 $\left(\mathrm{O}_{2}\right)$ が解離し, 中性の AOが発生している. 大気成分の 高度分布を大気モデル NRLMSISE- $00^{4)}$ で計算した結果を 図3に示す。地球の大気は 78 \%が窒素，21\%が酸素であ るが，図3に示すとおり，高度約 $200 \mathrm{~km}$ から $600 \mathrm{~km}$ にお いては, AOが大気の支配的な成分となり，高度約 400 $\mathrm{km}$ では 80 \%以上を占めている.

ISSが飛行する高度約 $400 \mathrm{~km}$ の AOの密度は約 $8 \times 10^{13}$ atoms $/ \mathrm{m}^{3}$ であり, 宇宙機の速度が約 $8 \mathrm{~km} / \mathrm{s}$ と高速である ことから，進行方向面のフラックスは $6.4 \times 10^{9}$ atoms $/ \mathrm{m}^{2} / \mathrm{s}\left(6.4 \times 10^{13}\right.$ atoms $\left./ \mathrm{cm}^{2} \cdot \mathrm{s}^{-1}\right)$ になる。

\section{2 材料劣化}

高分子材料が前項で述べたような宇宙環境に曝される と, 劣化が生じることが知られている. 環境因子と劣化の 関係を表 1 に示す ${ }^{6)}$. 宇宙環境因子毎に劣化モードが異な っていることがわかる.このことは, 宇宙機の軌道によっ

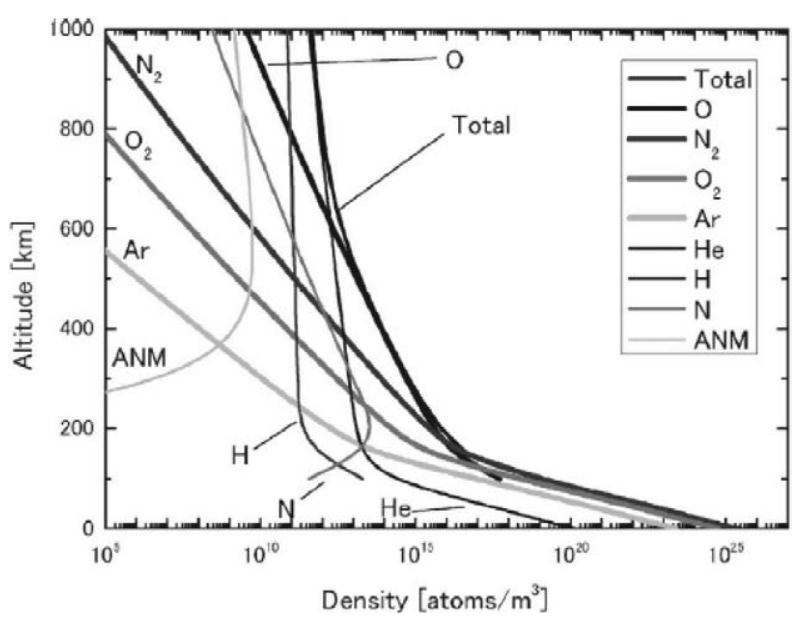

図3気体の分布と高度の関係5)

表1 宇宙環境因子と高分子材料劣化 ${ }^{6)}$

\begin{tabular}{|c|c|}
\hline 宇宙環境因子 & 高分子材料劣化 \\
\hline $\begin{array}{l}\text { 温度サイクル・ } \\
\text { 熱負荷 }\end{array}$ & $\begin{array}{l}\text { 熱ひずみ } \rightarrow \text { 形状変化, クラック, 剥離 } \\
\text { 温 } \rightarrow \text { 脆化 } \\
\text { 高温 } \rightarrow \text { 軟化 }\end{array}$ \\
\hline 原子状酸素 & 酸化分解 $\rightarrow$ 侵食 $\rightarrow$ 質量減少, 表面形態変化, 変色 \\
\hline 紫外線 & 分解 $\rightarrow$ 低分子化, 架橋 $\rightarrow$ 変色, 脆化 \\
\hline 放射線 & 分解 $\rightarrow$ 低分子化, 架橋 $\rightarrow$ 変色, 脆化 \\
\hline 高真空 & 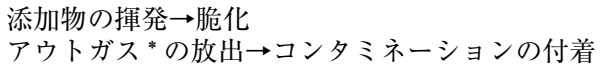 \\
\hline
\end{tabular}


て, 主要な宇宙環境因子が変わってくることを示している. すなわち LEOでは地球大気由来成分である AOの影響が 大きいが，GEOでは，AOの影響はほとんど無く，放射線 の影響が大きくなるという具合である。また，LEO， GEOいずれにおいても，UVに曝される。

\subsubsection{UVによる劣化}

UVのエネルギー（hv）を吸収した分子は励起状態に遷 移する。そして, 励起状態の分子が十分なエネルギーを有 していたとき，結合は分解し，ラジカルが生じる7).

$$
\begin{aligned}
& \mathrm{RH}+\mathrm{h} v \rightarrow \mathrm{RH}^{*} \\
& \mathrm{RH}^{*} \rightarrow \mathrm{R} \cdot+\mathrm{H} \cdot
\end{aligned}
$$

分解反応で生じたラジカルは，架橋等の分子結合変化を起 こす. 各波長の光が持つエネルギーと主な分子の結合解離 エネルギーの関係を図 4 に示す ${ }^{10)}$ 。先にも記載したが，宇 宙空間では太陽光の強度は波長約 $200 \mathrm{~nm}$ から強くなるこ とから，高分子材料の主要な結合の多くがUVで分解され る可能性が高い。こうして生じた分子結合の変化により, 高分子材料の強度低下，変色による特性劣化等が起こるこ とになる ${ }^{8), 9)}$.

\subsubsection{AOによる劣化}

前述のように, 宇宙機はLEOでは約 $8 \mathrm{~km} / \mathrm{s}$ で飛行して

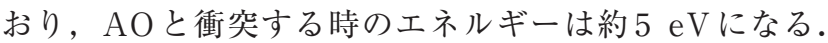
このため $\mathrm{AO}$ が高分子材料表面と衝突すると化学的及び物 理的変化が生じる。その概要を図 5 に示す ${ }^{11)}$ 。この結果,

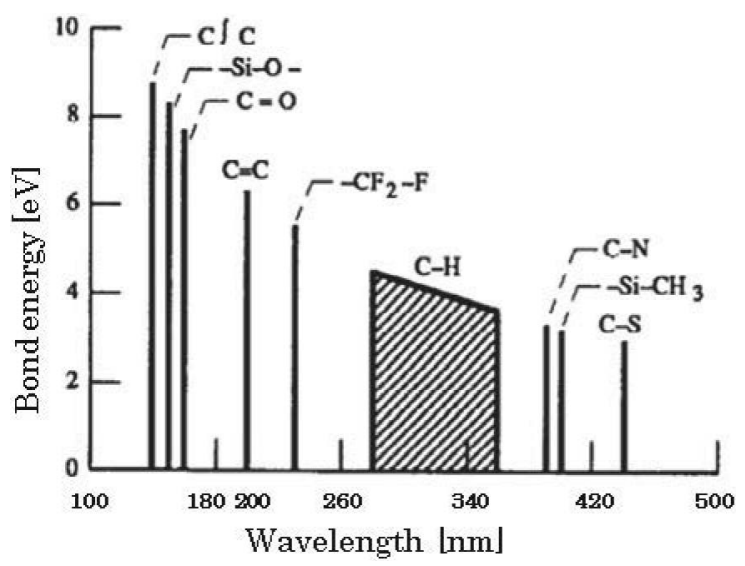

図4 光の波長と分子の結合解離エネルギーの関係 ${ }^{10)}$

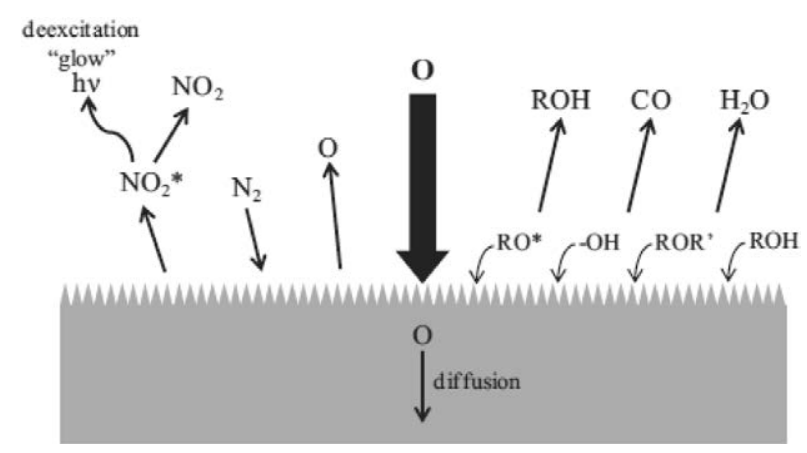

図 $5 \mathrm{AO}$ と高分子材料表面の反応 ${ }^{11}$
高分子材料は侵食され，質量減少，強度低下，特性変化を 生じることになる ${ }^{9,12)}$.

\section{3 劣化の実例及び宇宙曝露実験}

\subsection{1 宇宙機の劣化例}

実際の宇宙機でも高分子材料の劣化が観察されている. ISSに設置された太陽電池パドル端部のフィルムの破損を 図6に示す ${ }^{13)}$.元は一枚のフィルムであったが，破断しシ ワ状になっていることがわかる，使われたフィルムは，両 面に $\mathrm{Al}$ が蒸着されたポリイミドであり，Alコーティング の微小欠陥から $\mathrm{AO}$ が侵入し，ポリイミドを侵食したと考 えられている。

2009 年 5 月，ハッブル宇宙望遠鏡の熱制御ブランケット の交換が行われた。外観を図7に示す ${ }^{14)}$ 。図7（a）では長 方形の放熱エリアから複数の亀裂が，（b）では大きな亀 裂（円で示す）と片側がめくれ上がりカール（右下の亀裂） していることがわかる.

交換された 2 枚の熱制御ブランケットの最外層は，裏面 に Alが蒸着されたFEP (fluorinated ethylene propylene) であり，1990年 4 月の打ち上げから約 19 年宇宙環境に曝 された。地上に回収し分析された結果，特に機械的強度の 低下が大きいことが報告されている ${ }^{14)}$. 薄く割れやすい ガラスのように砕けやすくなっており, 地上での温度サイ クルや高温放置と同じ挙動であることから，熱負荷が分子 鎖を切断したと考えられている.
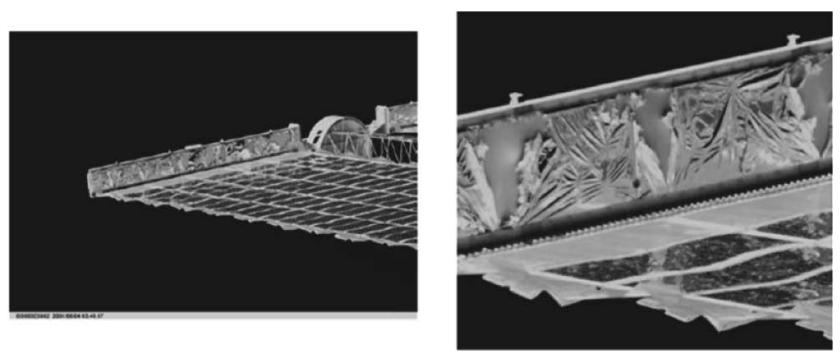

四6 ISS 太陽電池パドル端面に使用された両面 $\mathrm{Al}$ 蒸着ポリイミドフ イルムの破損 ${ }^{13}$
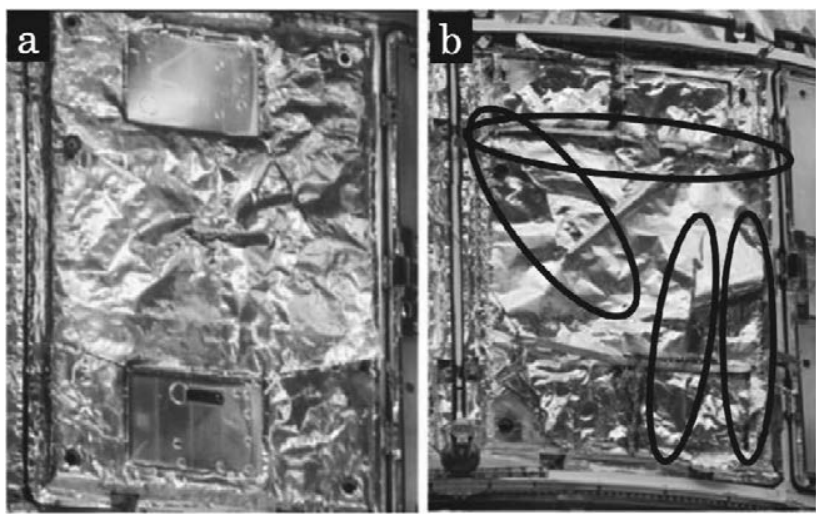

図7ハッブル宇宙望遠鏡の $\mathrm{Al}$ 蒸着 $\mathrm{FEP}$ フィルムの破損 ${ }^{14)}$ 


\subsection{2 材料曝露実験}

実際の宇宙環境に宇宙用材料を曝露し, 実宇宙環境の材 料に与える影響を評価する実験は，国内外でさまざまな実 験が実施されている。最近のJAXAの曝露実験では，微 小粒子捕獲及び材料曝露実験装置（MPAC\&SEED: MicroParticles Capturer and Space Environment Exposure Device）があり，ISSのロシアのサービスモジュールに設 置したSM/MPAC\&SEED（2001年 8月〜2005年 8月）と， 同じくISSの日本のきぼう船外実験プラットフォームに設 置したJEM/MPAC\&SEED（2009年 7 月〜 2010 年 4 月） の2つがある ${ }^{15)}$. 図8に設置状況を示す.

SM/MPAC\&SEED 実験は，搭載サンプルを含め全く同 じ構成の実験装置を 3 式製作し，これらを同時に打上げて ISS 後方のロシアサービスモジュールに設置した。 そして, 約 10 ヶ月, 約 28 ケ，約 46 ケ月の曝露を経て 1 式ずつ回 収した。この方法は世界初の試みであり，ほぼ同じ曝露環 境に扔ける材料の経年变化を直接比較することが可能であ る。一方，JEM/MPAC\&SEED実験は，ISS の進行方向に 対し前方のきぼうに設置されており，ISS自身からの污れ 等による影響が少ない宇宙環境に曝露することが可能であ る.

実験結果の一例として，ポリイミドフィルムを宇宙空間 に曝露した後のSEM 画像を図 9 に示す ${ }^{12)}$. 図 9 (a) は初 期の試料，（b）は地上で原子状酸素を照射した試料，(c) はSM / MPAC\&SEEDに搭載した試料，（d）は JEM/MPAC\&SEED に搭載した試料である。各画像は， 断面を出し，試料を傾けて撮影した。四 9 （c）の宇宙空 間に曝露した試料では，表面に付着物（contamination） の存在が認められる。図 9（d）の試料でも表面観察時に

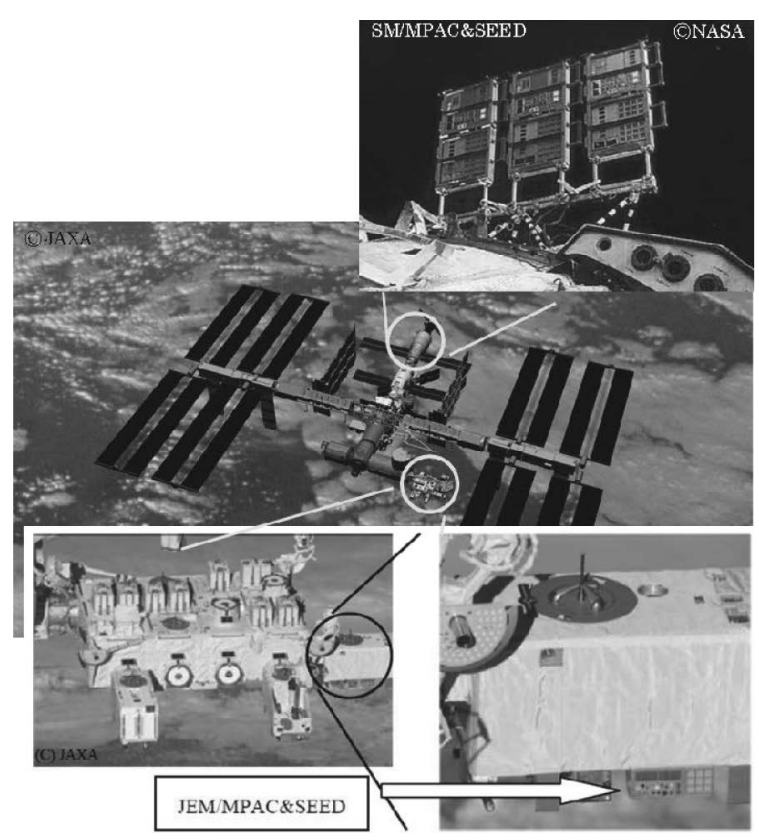

図 8 MPAC\&SEED 設置状況 ${ }^{15)}$
は付着物の存在を確認していたが，断面観察用試験片を作 成中に付着物が表面より剥離してしまったため，この画像 では付着物を確認することはできない. 両試料の付着物を EPMA で分析した結果， $\mathrm{SiOx}$ であると推定された。この ことから，付着物はシリコーンを多く含む材料（主に接着 剤）からアウトガスとして放出されたシロキサン成分が $\mathrm{AO}$ と反応することで形成されたものと考えられている. さらに，宇宙曝露試料では，地上で原子状酸素を照射した 図 9 (b) と同様の侵食が見られることに加え，局所的な 深い侵食が見られた。これは，表面の付着物による侵食阻 害効果と, 何らかの理由による付着物の剥離や損傷によっ て局所的に侵食されたことが原因であると予想されてい る.

上記以外の宇宙曝露実験結果も報告しているので，それ らも参照されたい $15-17)$.

\section{3. 地上模擬試験技術}

宇宙機は, 使用している材料が劣化しても, 修理や交換 することが容易ではない，その為，事前に十分な劣化評価 が必要であり，模擬試験技術が重要となる。JAXAでは, 地上で宇宙環境を模擬するため, 真空において $\mathrm{AO}$, 電子 線，UVを照射する設備を導入し運用している。本章では, 真空複合環境試験設備と, UV 照射試験設備について紹介 する.

\section{1 真空複合環境試験設備}

真空複合環境試験設備は，AO，真空紫外線（VUV： Vacuum Ultraviolet）及び電子線（EB: Electron Beam） の複合照射を行うことが出来る設備であり，1998年から 運用している．仕様を表 2 に示す．同時複合照射が可能な 設備は世界的に見てもユニークである．特筆すべきは $\mathrm{AO}$ で，大面積に対する高フラックスの $\mathrm{AO}$ 照射装置として，
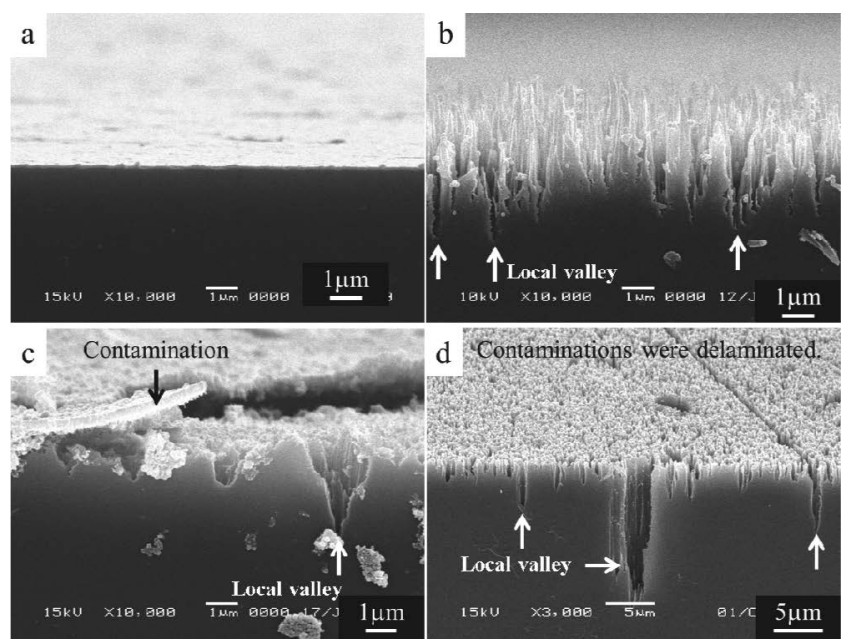

図9 ポリイミドフィルムの断面SEM画像 ${ }^{12)}$

（a）初期，（b）地上試験，（c）宇宙曝露（SM），（d）宇宙曝露 (JEM) 
世界屈指の能力を誇っている.

\subsection{UV 照射試験設備}

キセノンアークショートランプを光源とするUV照射試 験設備を 1984 年から運用している。その後，宇宙機の運 用軌道の多様化や設計定命の長寿命化等，UV照射試験の 需要が増え，1992年に2台目を，2009年に3台目を整備し 運用している．現在の仕様を表 3 に示す，真空環境におい て $15 \mathrm{~cm}$ 角と大きな照射面積に軌道上 10 倍加速の紫外線 を照射し，さらに試料温度を制御できる装置は世界で数少 ない. 試料温度を制御して軌道上 30 倍加速の紫外線を照 射できる装置は世界で唯一である。

\section{4. 材料劣化の研究例}

前章で紹介した設備を用いた材料劣化の研究例を示す. ここでは，UVの影響について調べた結果を紹介する．表

\section{表 2 真空複合環境試験設備の仕様 18}

\begin{tabular}{|c|c|}
\hline 項目 & 仕様 \\
\hline $\begin{array}{l}\mathrm{AO} \\
\text { 照射装置 }\end{array}$ & 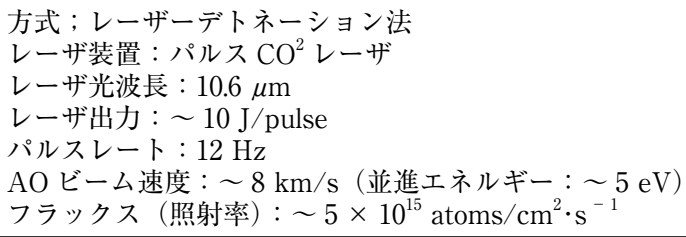 \\
\hline $\begin{array}{l}\text { VUV } \\
\text { 照射装置 }\end{array}$ & $\begin{array}{l}\text { 光源 : } 30 \mathrm{~W} \text { 重水素ランプ } \\
\text { ランプ数 : } 48 \text { 本 } \\
\text { ランプ電流 : } 250 \sim 350 \mathrm{~mA} \\
\text { 管電圧 }: 70 \sim 90 \mathrm{~V} \\
\text { フラックス (照射率) }: 0.2 \sim 0.25 \mathrm{~mW} / \mathrm{cm}^{2} \\
(120 \sim 200 \mathrm{~nm} \text { の積分強度 })\end{array}$ \\
\hline $\begin{array}{l}\mathrm{EB} \\
\text { 照射装置 }\end{array}$ & $\begin{array}{l}\text { ビーム走查 : X-Y 走查 } \\
\text { 加速電圧 : } 200 \sim 500 \mathrm{kV} \\
\text { 線源電流 : } 0.1 \sim 2.0 \mathrm{~mA} \\
\text { フラックス (照射率) }: 1 \mathrm{kGy} / \mathrm{min} \text { * }\end{array}$ \\
\hline 真空度 & $\begin{array}{l}10^{-5} \mathrm{~Pa} \text { 以下 } \\
\left(\mathrm{AO} \text { 照射時 : } 10^{-3} \sim 10^{-2} \mathrm{~Pa}\right)\end{array}$ \\
\hline 制御温度 & $-150 \sim 80^{\circ} \mathrm{C}$ \\
\hline サンプル & 標準寸法： $\phi 25 \mathrm{~mm}, t 3 \mathrm{~mm}$ 以下, 16 枚まで \\
\hline
\end{tabular}

表 3 紫外線照射試験設備の仕様

\begin{tabular}{|l|l|}
\hline 項目 & 仕様 \\
\hline 光源 & $\begin{array}{l}0.7 \sim 5 \mathrm{~kW} \\
\text { Xe アークショートランプ 1 本 }\end{array}$ \\
\hline 照射波長域 & $250 \sim 500 \mathrm{~nm}$ * \\
\hline $\begin{array}{l}\text { フラックス } \\
\text { (照射率) }\end{array}$ & $\begin{array}{l}11.8 \sim 118,354 \mathrm{~mW} / \mathrm{cm}^{2} \\
(200 \sim 400 \mathrm{~nm} \text { の積分強度 })\end{array}$ \\
\hline 照射面積 & $\begin{array}{l}15 \times 15 \mathrm{~cm}\left(11.8 \sim 118 \mathrm{~mW} / \mathrm{cm}^{2}\right) \\
10 \times 10 \mathrm{~cm}\left(354 \mathrm{~mW} / \mathrm{cm}^{2}\right)\end{array}$ \\
\hline フラックス分布 & $\pm 3 \%$ 以下 \\
\hline 真空度 & $10^{-4} \mathrm{~Pa}$ 以下 \\
\hline 制御温度 & 室温〜200 ${ }^{\circ} \mathrm{C}$ \\
\hline サンプル & 標準寸法 : $\phi 25 \mathrm{~mm}, t 5 \mathrm{~mm}$ 以下, 25 枚まで \\
\hline
\end{tabular}

※コーティング及びダイクロイックミラーでオゾンを発生する真空 紫外域と著しい温度上昇の原因となる赤外域をカット
1にあるように，UVは変色（黄変）の原因になる，UVフ ルエンスが多いほど黄変が強くなることは知られていた が，宇宙用の電線被覆材に広く用いられている電子線架橋 エチレンーテトラフルオロエチレン（X-ETFE, Raychem Spec 55/）の紫外線劣化の評価において，UV照射中の温 度が高いと黄変が強くなることを確認した ${ }^{19)}$ 。外観写真 を図 10 に示す。

これは，高温であるほどUVによる分子鎖切断で生じた ラジカルの拡散が顕著になり，結合状態の変化が促進され るためだと考えられる.

また，汎用高分子材料のポリエーテルエーテルケトン (PEEK)，ポリエチレンナフタレート (PEN)，ポリウレ タン（DUS601）に対して, 試料温度と, UVフルエンス を固定し，UVの照射強度を軌道上の 2 倍，10倍，30倍で 照射を実施した。照射前後の太陽光吸収率の変化量を図 11 に示す ${ }^{20)}$ 。試料温度を一定に保つことで，照射強度に よる太陽光吸収率の変化に有意差は見られなかった。

図 10 と図 11 から，真空中での材料のUV劣化は，フルエ ンスと温度が支配的である可能性が高いことがわかった。

\section{5. ま と め}

宇宙環境とそこで活躍するソフトマテリアル（高分子材 料）への影響について概説した。原子状酸素による侵食， 紫外線の分子結合変化による黄変等，高分子材料の変化や 劣化を理解した上で，宇宙機に使用しなければならない。 そのため，どのように劣化するか地上で事前評価を行う必 要がある、筆者の部門では，設備を導入，運用し材料評価 を行っている，さらに，実宇宙環境での材料劣化をより理 解するため, 軌道上における材料曝露実験も行っている.

以上のような宇宙用材料技術が地上用技術として応用さ

\begin{tabular}{|c|c|c|}
\hline UV & \multicolumn{2}{|c|}{ 試料温度 } \\
\hline$\left(\mathrm{ESD}^{*}\right)$ & $313 \mathrm{~K}$ & $373 \mathrm{~K}$ \\
\hline 0 & & \\
\hline 15 & & \\
\hline 30 & & \\
\hline 60 & & \\
\hline
\end{tabular}

*Equivalent solar days, $1 \mathrm{ESD}=1.02 \times 10^{3} \mathrm{~J} / \mathrm{cm}^{2}$ 図 10 UV 照射によるレイケム 55 電線被覆材の外観変化 ${ }^{19)}$ 


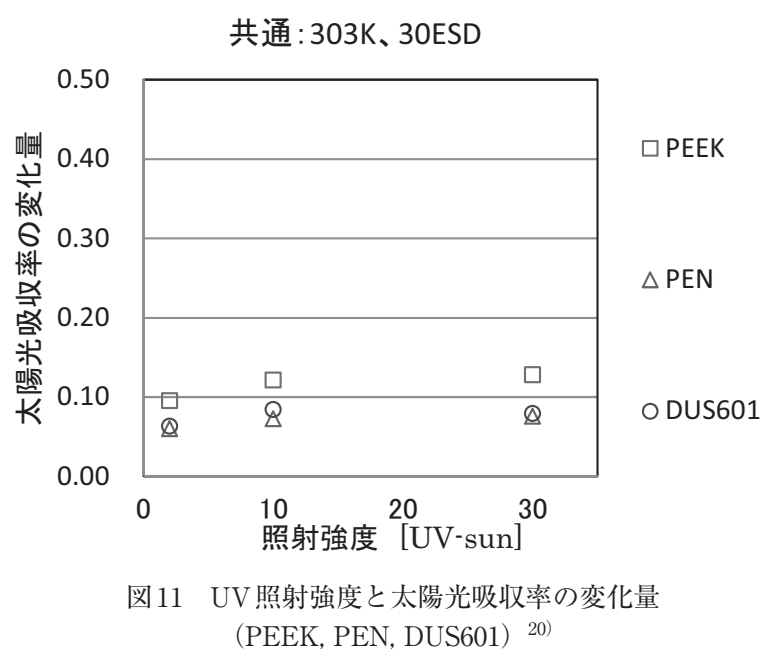

れソフトマテリアル（高分子材料）の発展に貢献すること を願っている。

\section{References}

1 ) Yokota, R.: MATERIAL STAGE, 10, 3 (2010)

2 ) ASTM E 490-00a, Standard Solar Constant and Zero Air Mass Solar Spectral Irradiance Tables (2006)

3 ) ASTM G173-03, Standard Tables for Reference Solar Spectral Irradiance:Direct Normal and Hemispherical on $37^{\circ}$ Tilted Surface (2008)

4 ) Picone, J. P.; Hedin, A. E.; Drob, D. P.; Aikin, A. C.: J. Geophys. Res., 107, 1468 (2002)

5 ) Kimoto, Y.; Miyazaki, E.; Ishizawa, J.; Shimamura, H.: J. Vac. Soc. Jpn., 52, 475 (2009)

6 ) Yokota, R.: Nippon Gomи Kyokaishi, 79, 22 (2006)

7 ) Slemp, W. A.: NASA CP 3035, 425 (1988)

8 ) Sasaki, N.; Nakamura, T.; Oguma, H.; Shimamura, H.: Trans. Jpn.
Soc. Mech. Eng. A, 76, 422 (2010)

9) Imagawa, Y.: “Science for Space Utilization Research”, Shokabo, Tokyo, 205 (2000)

10) Dever, J. A.: NASA TM 103711 (1991)

11）Banks, B. A.; Rutledge, S. K.; Brady, J. A.; Merrow, J. E.: NASA CP 3035, 197 (1988)

12) Shimamura, H.; Kimoto, Y.; Nakamura, T.: Astrophys. Space Sci. Proc., 32, 283-294 (2011)

13) Banks, B. A. ; Demko, R.: NASA TM 211360 (2002)

14) de Groh, K. K.; Waters, D. L.; Mohammed, J. S.; Perry, B. A.; Banks, B. A.: Astrophys. Space Sci. Proc., 32, 13-26 (2011)

15) Kimoto, Y.; Ishizawa, J.; Shimamura, H.: Astrophys. Space Sci. Proc., 32, 73 (2011)

16) Miyazaki, E.; Kimoto, Y.; Yokota, R.: Astrophys. Space Sci. Proc., 32, 295 (2011)

17) Proceedings of International Symposium on "SM/MPAC\&SEED Experiment" , JAXA-SP-08-015E (2009)

18) Shimamura, H.; Baba, S.; Miyazaki, E.: "Handbook of the Combined Space Effects Test Facility”, Japan Aerospace Exploration Agency, JAXA-RM-10-013 (2011)

19) Ishizawa, J.; Mori, K.: Proceedings of the $11^{\text {th }}$ International Symposium of Materials in a Space Environment (2009)

20) Mori, K.; Ishizawa, J.: Materials Life Society $24^{\text {th }}$ Kenkyu Happyokai Yokoshu, 25 (2013)

\section{日本語表記参考文献}

6 ）横田力男：日本ゴム協会誌，79，22（2006）

8 ）佐々木望; 中村 孝; 小熊博幸; 島村宏之：機会学会論文集 A 編，76，422（2010）

9 ) 今川吉郎：“宇宙環境利用のサイエンス”, 裳華房, 東京, 205 (2000)

18）島村宏之；馬場勧；宮崎英治：“真空複合環境試験設備ハンド ブック”，宇宙航空研究開発機構，JAXA-RM-10-013 (2011)

20）森一之; 石澤淳一郎：マテリアルライフ学会 第 24 回研究発表 会予稿集，25(2013) 